Discussion Paper No. 13-114

\title{
Profit-Sharing and Innovation
}

Kris Aerts, Kornelius Kraft, and Julia Lang

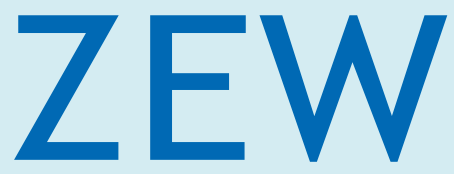

Zentrum für Europäische Wirtschaftsforschung $\mathrm{GmbH}$

Centre for European Economic Research 
Discussion Paper No. 13-114

\title{
Profit-Sharing and Innovation
}

\author{
Kris Aerts, Kornelius Kraft, \\ and Julia Lang
}

Download this ZEW Discussion Paper from our ftp server:

http://ftp.zew.de/pub/zew-docs/dp/dp13114.pdf

Die Discussion Papers dienen einer möglichst schnellen Verbreitung von neueren Forschungsarbeiten des ZEW. Die Beiträge liegen in alleiniger Verantwortung der Autoren und stellen nicht notwendigerweise die Meinung des ZEW dar.

Discussion Papers are intended to make results of ZEW research promptly available to other economists in order to encourage discussion and suggestions for revisions. The authors are solely responsible for the contents which do not necessarily represent the opinion of the ZEW. 


\section{Non-Technical Summary}

We investigate the effect of profit sharing on product and process innovation. The general aim of companies introducing profit sharing in their remuneration policy is to stimulate staff performance. As profit maximization becomes a win-win strategy to both the employees and the firm owners, their mutual interests become aligned. If the incentive system works in an efficient way and if employees behave rationally, they will increase their efforts, which should subsequently raise the company's performance.

While many studies consider the effects of profit sharing on firm performance in general (productivity, profitability), not much is known about the effects on innovation. In this paper, we introduce measures of technological progress in an attempt to unravel how profit sharing may interact with firm performance through the realisation of both product and process innovations. We employ the IAB establishment panel, an extensive dataset on German establishments over the time periods 2005 to 2009. In order to eliminate possible selectivity effects, we apply static matching and conditional difference-in-differences methods.

Based on the matching results, profit sharing companies outperform non-profit sharing companies on both process and product innovativeness. However, according to the results of the conditional difference-in-differences method only product innovation is enhanced by the introduction of profit sharing. Hence firms introducing profit sharing are already more innovative with respect to both product and process innovations before they launch the variable incentive method of profit sharing. But profit sharing additionally has a positive effect on product innovations. 


\section{Das Wichtigste in Kürze}

Wir untersuchen die Auswirkungen von Gewinnbeteiligung auf Produkt- und Prozessinnovationen. Das allgemeine Ziel der Unternehmen bei der Einführung von Gewinnbeteiligung als Element der Einkommenspolitik ist die Motivierung der Beschäftigten zu einer höheren Leistung. Da Gewinnbeteiligung für beide Seiten einen Vorteil darstellt, kann sich eine größere Übereinstimmung der Interessen der Arbeitnehmer und der Kapitaleigner entwickeln. Bei einer effizienten Ausgestaltung des Anreizsystems und rationalem Verhalten der Beschäftigten sollte sich der Unternehmenserfolg erhöhen.

Während viele Studien die Auswirkungen von Gewinnbeteiligung auf die Unternehmensleistung im allgemeinen (Produktivität, Gewinnhöhe) untersuchen, gibt es wenig Evidenz hinsichtlich der Effekte auf den Innovationserfolg. In der hier präsentierten Untersuchung führen wir Erfolgsmaße für Innovation ein und betrachten die Auswirkungen der Einführung von Gewinnbeteiligungsmodellen auf Produkt- und Prozessinnovationen. Wir verwenden das IAB-Betriebspanel als eine umfangreiche Datengrundlage zu deutschen Betrieben über die Jahre 2005-2009. Die Möglichkeit einer Verzerrung der Ergebnisse durch Selektionseffekte wird über zwei Methoden berücksichtigt. Einerseits werden statische Vergleiche zwischen Firmen mit und ohne Gewinnbeteiligung durchgeführt. Hierbei werden Unterschiede zwischen den Betrieben mit und ohne Gewinnbeteiligung hinsichtlich der Ausprägungen der exogenen Variablen über das Matching-Verfahren eliminiert. Andererseits identifizieren wir die Betriebe, welche eine Gewinnbeteiligung eingeführt haben und betrachten die Auswirkungen dieser Einführung in einem konditionalen Differenz-inDifferenzen Ansatz.

Auf der Grundlage der Ergebnisse des Matching Ansatzes sind Betriebe mit Gewinnbeteiligung denjenigen ohne Beteiligung sowohl in Hinsicht auf Prozess- als auch Produktinnovationen überlegen. Bei dem bedingten Differenz-in-Differenzen Ansatz findet sich jedoch ein positiver Effekt der Gewinnbeteiligung lediglich hinsichtlich von Produktinnovationen. Folglich sind die Betriebe, welche Gewinnbeteiligung einführen, bereits vorher innovativer. Gewinnbeteiligung kann jedoch den Erfolg bei Produktinnovationen noch weiter erhöhen. 


\title{
Profit-Sharing and Innovation
}

\author{
Kris Aerts * \\ Kornelius Kraft ${ }^{\#}$ \\ Julia Lang ${ }^{+}$
}

December 2013

\begin{abstract}
We investigate the effect of profit-sharing on product and process innovation. Profit-sharing is a credible commitment of the companies to let the employees participate in any efficiency gain. Resistance against technical progress becomes less plausible. Moreover, employees are stimulated to share their specific information advantage on possibilities to optimize the production process and products with the management. We take account of possible selectivity effects and using survey data on German companies with and without profitsharing in a conditional difference-in-differences framework, we test our hypothesis by comparing measures of innovativeness. Based on matching (selectivity on observable covariates) in a static comparison firms with a share system show both more product and process innovations. In a dynamic setting, we find that the introduction of profit-sharing only spurs product innovation.
\end{abstract}

Keywords: Profit Sharing, Innovation, Matching, Difference-in-Differences

JEL Codes: L23, L25, O31, O32

* CEGEKA, Belgium. Correspondence: CEGEKA Interleuvenlaan 16, B-3001 Leuven, Belgium.E-mail: kris.aerts@cegeka.be

\# Technical University of Dortmund, IZA and ZEW, Germany. Correspondence: University of Dortmund, Department of Economics, Vogelpothsweg 87, D-4427 Dortmund, Germany. Email: kornelius.kraft@uni-dortmund.de

+ Institute for Employment Research (IAB), Germany. Correspondence: Institute for Employment Research (IAB) of the German Federal Employment Agency (BA), Regensburger Strasse 104, D-90478 Nuremberg, Germany.E-mail: Julia.Lang@iab.de

\footnotetext{
* The authors are grateful to the Institute for Employment Research (IAB) for providing the data with remote access. This paper was initiated during a short research visit of Kris Aerts to the Technical University of Dortmund. She is grateful for the university's hospitality. Moreover, the comments of Dirk Czarnitzki, Koen Debackere, Pierre Mohnen and Reinhilde Veugelers are highly appreciated.
} 


\section{Introduction}

Knowledge has become a fundamental economic asset (see e.g. Romer [1990]) and determines companies' competitive strength (Schumpeter [1942]). On the one hand, knowledge creation is a time and money consuming process, with an uncertain outcome (Dasgupta and Maskin [1987]). Optimal staff motivation is to the benefit of expected success. On the other hand, knowledge spreads relatively quickly into the public domain once it has been created, allowing other companies to take advantage of the originating company's investments. Mansfield [1985] showed that a significant share of knowledge leaks out through employees. Therefore, in knowledge creating companies, it is vital to attract valuable employees and curtail the staff turnover and additionally, to motivate this highly qualified workforce. One important aspect is employee remuneration. A vast body of research is devoted to investigating optimal remuneration systems and it appears that monetary as well as non-pecuniary incentives matter (see e.g. Coombs and Gomez-Mejia [1991]), jointly optimized in a stimulating work environment with an attractive remuneration system. In this paper, we zoom in on one specific remuneration system, namely profit ${ }^{1}$ sharing: employees share in the profit of a company, through the receipt of financial rewards, depending on the company's performance. Often, this financial incentive is disbursed as a supplement to the fixed base wage (see Kraft and Ugarković [2007], Bhargava and Jenkinson [1995] as well as Wadhwani and Wall [1990]).

The direct aim of companies introducing profit sharing in their remuneration policy is to stimulate staff performance. As profit maximization becomes a win-win strategy to all parties involved, i.e. both the employees and the firm owners, their mutual interests become aligned. If the incentive system works in an efficient way and if employees behave rationally, they increase their efforts, which should subsequently raise the company's performance (see Kraft and Ugarkovic 2006). Since a considerable time, profit sharing has been the subject of many empirical studies (see e.g. Pérotin and Robinson [2002] as well as Strotmann [2002] for elaborate surveys of this literature stream). The direct link between profit sharing and output explains why traditionally productivity has by far been the most often investigated issue in this research domain. Less frequently investigated topics are the effects on profitability and wages. The latter variable is investigated as Weitzman [1983] suggested using profit sharing as an alternative, instead of a supplement to the going wage rate. 
Scholars typically find positive to neutral impacts of profit sharing on a firm's output. However, productivity measures only show part of the picture, as they merely reflect the final impact, without illuminating possible reasons explaining this productivity increase. An efficient incentive system is expected to affect workers' performance, but may additionally strengthen a company's innovative capabilities, as theoretical arguments predict that potential resistance against innovative activity can be offset and what is even more, employees may actively cultivate the company's innovative capabilities.

In this paper, we introduce measures of technological progress in an attempt to unravel how the introduction of profit sharing may interact with firm performance through the realisation of both product and process innovations. This area has remained by and large unexplored until now. We employ an extensive dataset on German firms. In order to eliminate possible selectivity effects, we apply conditional difference-in-differences methods. In the second section, we briefly summarise the history of research on profit sharing and advance some theoretical considerations. The third section entails the strategy we follow in the empirical part, which is subsequently presented in two sections, covering the data description and the estimation results. The last section concludes with a summary of our findings, some limitations of our research set-up and lines for further research.

\section{Literature summary and theoretical arguments}

The literature on profit sharing can be categorized into two substreams. The first substream, which is especially supported by the European Community (see the so-called Pepper reports: Commission of the European Communities [1991, 1996] and Lowitzsch [2006]), tries to provide a framework for international comparisons and to quantify the prevalence of profit sharing in Europe and the US. However, definition problems and internationally different legislation schemes seriously complicate these studies and imply strong limitations with respect to their comparability.

The second substrea*m of literature investigates the potential impact of profit sharing on various company characteristics. As mentioned before, the traditionally most investigated variable in this domain is productivity. The interested reader is referred to FitzRoy and Kraft [1987] as one of the first studies, Doucouliagos [1995] for a meta-analysis and to Pérotin and Robinson [2002] as well as Strotmann [2002] for elaborate surveys of the extensive literature. Overall, the conclusions tend to confirm small but positive productivity increases as a result 
of profit sharing. Other variables which are studied in relationship with the existence of profit sharing are wages and labour demand (see Pérotin and Robinson [2002]), as well as profitability (Kraft and Ugarković [2006]). An important issue, which is nevertheless often ignored, is the fact that different selection mechanisms may play a part when studying profit sharing and its impact. This may seriously distort evaluation exercises and undermines the validity of the results. In the methodological section, we will extensively come back to this issue of selectivity.

To the best of our knowledge, no studies exist on the impact of profit sharing on the innovative performance of companies. However, in the subsequent paragraphs we will advance theoretical arguments and predict a potential positive impact of this specific remuneration system on the company's innovation process.

Although a high-quality workforce is expected to produce highly valuable $R \& D$ and innovative output, there are two main motives why employees may hamper innovative activity. First, employees are expected to dislike technological change if its introduction implies re-training, alternative work organizations and adaption costs, in addition to potential dismissals. Training will most likely be firm-specific and thus the risk for the workers increases, which may therefore excite opposition against innovative activities within the company. Schaefer [1998] found that these frictions do not necessarily obstruct innovative activity, but nevertheless may seriously slow down or change the innovation process. Zwick [2002] proves that internal resistance against innovation is more likely if it is uncertain whether the employees benefit from the investment. Our second argument as to why employees may negatively affect a company's technological progress and innovative capabilities works more directly. New technologies may enable companies to substitute labour by capital. This in turn may lower the demand for labour and therefore reduce employment and/or wages. As a result, employees may exhibit a substantial scepticism or even negative attitude towards technological progress. In that case, any attempt to modernize the company's technological equipment or to conduct process innovations will be distrusted or even opposed.

Profit sharing can provide an effective remedy to counter or even upturn these frictions and the potential negative pressure of human capital on R\&D. First, the premium offered through profit sharing can be regarded as a compensation for the training and subsequent risk. Therefore, profit sharing may moderate employee opposition against technological advancement. Second, profit sharing may even stimulate the employees' incentives to actively 
support and contribute to process innovations. As profit sharing entails an explicit commitment on behalf of the company owners to share part of the profits with the employees, their mutual interests are aligned towards one denominator: profit maximization. Process innovations are expected to increase a company's future profits, so technological progress is to the benefit of both parties. Employees are closely involved in the company's bench level expertise and may therefore possess an information advantage on potential weaknesses and inefficiencies of the technologies in use. Without profit sharing there is hardly any incentive to disclose this information to the management. However, when employees participate in any profit increase, it is in their self-interest to fully exploit all available information. Hence, if the company employs a profit sharing system, employees will be less averse towards strengthening the company's technological equipment, and, even more important, they may become a valuable asset in the process of technological progress. In this paper, we therefore advance the hypothesis that profit sharing fosters process innovation.

At first glance less obvious but possibly also present is an effect of profit sharing on product innovation. During the production process, employees go through a learning curve: they accumulate knowledge, gain experience and subsequently may come up with ideas to improve a product's quality. If a monetary incentive is coupled to the implementation of any useful suggestion on a product improvement, the likelihood that the employee discloses his ideas obviously increases. Similarly, employees may become aware of potentially interesting additional features of the produced goods. Hence, while it seems unlikely that employees can contribute significantly to the development of totally new products, they may possess a substantial potential to improve existing products to a significant extent. Moreover, some employees closely interact with the company's customers and as a result are well aware of their preferences. They gather information on potential shortcomings of the existing product range as well as the customers' needs and wishes concerning improvements of existing as well as desired features of future products. This valuable knowledge should be transferred to the company's R\&D department, in order to develop products along these lines. If the company succeeds in complying with these requirements, its market success is expected to rise and consequently also its sales of improved or newly developed products. Profit sharing generates clear incentives to share this information with the management as, in contrast to the traditional wage-based firm, its capitalization is shared with the source of information: the employee. In summary, our theoretical arguments predict that introducing profit sharing has the potential to stimulate both process and product innovation. 


\section{Empirical Strategy: the treatment of selectivity}

Although many empirical studies confirm the hypothesis that profit sharing has a neutral to significantly positive effect on the company's performance, only a surprisingly small minority of firms actually employs this remuneration scheme. The percentage of firms with a profit sharing system is quite low in the European Union, except in France and the United Kingdom, where financial participation in companies is supported by a legal framework and substantial tax advantages (see Poutsma [2001] for an extensive description of country differences in the European Union). This seems to indicate that profit sharing is not a beneficial strategy to all companies, but only to certain firms. Strotmann [2002] denounces the fact that, even after the clear conclusion of FitzRoy and Kraft [1995] that different selectivity mechanisms may play a role in the evaluation of profit sharing, many studies do not or not sufficiently control for the potential distortion of the results due to these selection biases. This section first clarifies the different arguments supporting expectations about the presence of selectivity. Next, we expound how this problem is solved in our empirical analysis.

A first reason for the rather low ratio of firms employing profit sharing might originate in firm-specific advantages or disadvantages with respect to different incentive schemes. Companies presumably differ in a number of aspects. For instance, the respective workforces may exhibit different qualification levels. Furthermore, firms may differ in their capability to validate individual performance. Examples are highly structured work processes, e.g. in the extreme belt production, or a team-based production process, where only joint, i.e. not individual, output is observed. In general, smaller firms suffer significantly less from problems in measuring individual employee performance. Other differences may stem from turnover rates, the workforce's cultural and ethical background, industrial relations and many other characteristics. In these circumstances, it is reasonable to believe that firms that are able to capture specific advantages from profit sharing are likely to introduce this incentive scheme in their remuneration policy, while others show no interest and rather rely on other motivational instruments like tournaments, piece rates or efficiency wages. A second kind of selectivity is driven by worker sorting. Performance oriented and cooperative workers probably prefer working in profit sharing firms. These workers are presumably more productive, irrespective of the presence of a profit sharing scheme. Moreover, the strong presence of productive and highly skilled employees may increase the productivity of less productive employees through mutual and cooperative learning efforts. In this case, these 
employee teams differ from teams in the more traditional firms paying fixed wages. This very likely causes differences in any performance measure, including innovativeness. Furthermore, it is quite realistic to assume that employees behave risk-averse and prefer a fixed wage over a variable, performance-related pay. If, for a moment, we set aside the argument raised before, i.e. that profit sharing usually complements the fixed wage, instead of replacing it, firms paying a flexible wage presumably attract less risk-averse workers. It is not unreasonable to assume that these employees are also more productive. Finally, selectivity in innovation activities may arise. It is quite plausible that highly innovative companies also use efficient incentive systems, simply because they are managed in a better way. Hence, a positive correlation between innovative activity and the use of profit sharing in the remuneration policy may be due to an unobserved third factor, while actually no causal relation exists.

If selectivity is at work, any empirical methodology neglecting this problem will produce biased results. Using the Heckman estimator, the early study of FitzRoy and Kraft [1995] confirms the strong presence of selectivity effects. Profit sharing is proved to be endogenous with respect to any outcome measure. Another sophisticated method to deal with selectivity is the non-parametric matching approach, well known in the so-called treatment analysis. Treatment in our case is defined as the use of profit sharing. This methodology goes back to Roy [1951] and Rubin [1974] and has also been labelled the potential outcome approach. A matching approach re-establishes the conditions of an experiment and compares treated and non-treated observations. The control sample of non-treated companies is selected carefully, to maximize its similarity with the population of treated companies. Every single treated company is related to non-treated units: conditioning on their similarity, a non-treated firm receives a high or low weight, or even is omitted. The determination of the control observation's importance (weight) depends on the selected matching estimator (see Heckman et al. [1997]).

Rubin [1974] defines the impact of the treatment as the difference between the likely outcome $\mathrm{Y}$ of an establishment ${ }^{2}$ introducing profit sharing, $\mathrm{Y}^{1}$, and the counterfactual outcome in the case of non-introduction, $\mathrm{Y}^{0}$, given $\mathrm{D}=1$ :

$$
\theta=E\left(Y^{1}-Y^{0} \mid D=1\right)=E\left(Y^{1} \mid D=1\right)-E\left(Y^{0} \mid D=1\right)
$$

where $\mathrm{D}$ is a binary assignment indicator determining whether the firm has introduced profit sharing $(D=1)$ or not $(D=0)$. Parameter $\theta$ measures the average treatment effect on the treated 
firms and determines whether the use of profit sharing is beneficial to those establishments that introduced this incentive scheme in their remuneration policy.

The fundamental problem in evaluation econometrics arises from the fact that the second term on the right hand side, i.e. the counterfactual outcome $\mathrm{E}\left(\mathrm{Y}^{0} \mid \mathrm{D}=1\right)$, is by definition not observable, since it describes the hypothetical outcome of a firm that actually introduced profit sharing if it would not have done so. In the absence of selectivity, the following equality:

$$
E\left(Y^{0} \mid D=1\right)=E\left(Y^{0} \mid D=0\right)
$$

would hold and the average outcome of firms without profit sharing would provide an estimate for $E\left(Y^{0} \mid D=1\right)$. This assumption is valid in an experiment where randomisation of the treatment is given. However, as FitzRoy and Kraft [1995] have shown and as we argued before, it is quite unlikely that profit sharing and non-profit sharing firms do not differ with respect to certain characteristics: profit sharing is endogenous, which introduces a bias in the estimates. The key to solve this evaluation problem is to approximate the counterfactual outcome. We chose to follow the potential outcome (i.e. matching) approach and, in a second step, additionally consider a time dimension, by applying the so-called conditional differencein-differences technique. In the following paragraphs we explain the details of this methodology.

Rubin's [1977] conditional independence assumption (CIA) states that the treatment status and the potential outcome are independent for observations exhibiting the same observable set of characteristics X. The validity of the CIA depends on whether all determinants influencing the decision to introduce profit sharing as well as the potential outcome are known and available for all observations. However, the CIA cannot be tested formally and as a result, the researcher is obliged to rely on the data quality. We believe that the IAB Establishment Panel, which will be described in more detail below, covers a wide array of information, ranging from general information on the establishments to questions on investment, business policy and development to employment-related questions, and therefore serves as a good basis to fulfil this requirement.

Hence, if sample selection is solely due to observable covariates (a vector X), the CIA applies and the following equation holds:

$$
E\left(Y^{0} \mid D=1, X=x\right)=E\left(Y^{0} \mid D=0, X=x\right) .
$$


The treatment effect $\theta$ in the matching approach can consequently be estimated by comparing the outcome means of the two groups (Lechner [1998]):

$$
\theta_{M}=E\left(Y^{1} \mid D=1, X=x\right)-E\left(Y^{0} \mid D=0, X=x\right) .
$$

In practice, ensuring the validity of the CIA imposes a major obstacle, since every additional exogenous variable in the vector $\mathrm{X}$ decreases the probability of finding an adequate control group. Rosenbaum and Rubin [1983] proposed a remedy to this dimensionality problem. As an alternative to matching on a large set of covariates, their idea is to match on one single index. This so-called propensity score is estimated with information on the exogenous characteristics X. Rosenbaum and Rubin [1983] show that, if the CIA is fulfilled, one does not need to condition on all covariates contained in $\mathrm{X}$, but only on the propensity score. In our case, this index is estimated as the conditional probability to use profit sharing, i.e. the probability to share profits with the employees, given a set of individual characteristics of a firm: $\operatorname{pr}(\mathrm{D}=1 \mid \mathrm{X}=\mathrm{x})$. This propensity score is usually estimated in a probit model.

Several matching methods have been proposed in the literature on evaluation econometrics. We employ nearest neighbour matching, which comes down to a pair wise matching as it tries to select the most similar non-treated observation (ideally a "twin") for every treated observation. If the matching procedure was successful, i.e. the establishments that did (treated group) and did not (selected control group) use/introduce profit sharing are ex ante equally likely to use/introduce profit sharing, equation (3) holds and the causal effect is computed as indicated in equation (4), by comparing the outcome means of the two groups.

The matching approach accounts for the selection bias caused by observable factors. However, as we mentioned before, compliance with the CIA is crucial to obtain reliable estimates: all relevant information should be known and available for all observations. Although we strongly believe that our data at hand are very rich, nonetheless, unobservable factors may be at work and affect the outcome variable. This could seriously bias the results. To correct for this potential selection on unobservables more strongly, the initial matching method can be extended with a time dimension.

This is exactly what we will additionally do in the empirical part of this paper, as we have a rich two-period panel dataset at our disposal. We present two evaluation methods, assessing the evolution of the outcome $\mathrm{Y}$ after treatment. Besides a matching approach, matching and difference-in-differences techniques are combined in the second method, which is referred to as the conditional difference-in-differences (CDiD) or matched difference-in- 
differences approach (Heckman et al. [1997]). When we only take into account selection on observable factors, we use a cross-section sample of firms which apply profit sharing in 2009 and compare them with a matched sample of firms without profit sharing. For the CDiD approach we concentrate on firms which introduced profit sharing between 2005 and 2009 and firms which never used profit sharing during this time period.

The general difference-in-differences (DiD) set-up relates the development of an outcome variable of treated observations to the evolution of this outcome variable in a control group of non-treated observations. The before-after change in the outcome of non-treated firms is subtracted from the before-after change in the outcome of the treated firms to obtain the average treatment effect $\theta$ :

$$
\theta_{D i D}=E\left(Y_{t_{1}}^{1}\left|D=1-Y_{t_{0}}^{1}\right| D=1\right)-E\left(Y_{t_{1}}^{0}\left|D=0-Y_{t_{0}}^{0}\right| D=0\right),
$$

where $D$ denotes whether the unit under consideration is treated $(D=1)$ or not $(D=0), Y$ is the outcome variable and $t$ represents the moments in time before $\left(t_{0}\right)$ and after $\left(t_{1}\right)$ the introduction of the measure. The DiD estimator thus measures the excess outcome growth of the treated as compared to the non-treated group, correcting for any macro-economic change over time. Including additional regressors $\mathrm{X}$ combines the advantages of the matching and the DiD approach (Blundell and Costa Dias [2000]): the impact of profit sharing is evaluated over time, for twin samples of firms with and without profit sharing. This conditional differencein-differences (CDiD) approach eliminates time-invariant unobserved individual-specific effects as well as common macro trends. Several studies evaluating active labour market policies make use of this estimator (e.g. Kluve et al. [1999], Eichler and Lechner [2002], Bergemann et al. [2004]). The treatment and control group are matched on observable characteristics X such that:

$$
\left(Y_{t_{1}}^{1} \mid D=0, X=x\right)-\left(Y_{t_{0}}^{1} \mid D=0, X=x\right)=\left(Y_{t_{1}}^{0} \mid D=0, X=x\right)-\left(Y_{t_{0}}^{0} \mid D=0, X=x\right) .
$$

To increase the accurateness and quality of the matching process, additional activities were carried out. For all treated firms a valid counterpart should be found in the non-treated population and every firm should represent a potential profit sharing company. If the samples of treated and non-treated firms would have no or only little overlap in the exogenous characteristics $\mathrm{X}$, matching is not applicable to obtain consistent estimates. Hence, the socalled common support restriction is imposed and all firms exhibiting extreme values and therefore complicating the matching process are removed. We employ the conditional 
difference-in-differences approach with nearest neighbour propensity score matching and match without replacement, which means that every control observation can only be used once for matching. The average treatment effect $\theta$ is calculated as follows:

$$
\theta_{C D i D}=\left(E\left(Y_{t_{1}}^{1} \mid D=1, X=x\right)-E\left(Y_{t_{0}}^{1} \mid D=1, X=x\right)\right)-\left(E\left(Y_{t_{1}}^{0} \mid D=0, X=x\right)-E\left(Y_{t_{0}}^{0} \mid D=0, X=x\right)\right) .
$$

We match firms which introduced profit sharing between period $t_{0}$ and $t_{1}$ to firms which have never shared profits, using their respective vectors of exogenous characteristics $\mathrm{X}$ in period $t_{0}$. Then, we evaluate how the outcome $\mathrm{Y}$ of both groups (treated versus non-treated subjects) has evolved over time, comparing static (assessing $\mathrm{Y}$ in period $\mathrm{t}_{1}$ ) and dynamic (comparing $\mathrm{Y}$ in the periods $\mathrm{t}_{0}$ and $\mathrm{t}_{1}$ ) variables for the treated and non-treated firms in $\mathrm{t}$-tests on mean equality ${ }^{3}$.

\section{The data}

This section describes the data which will be used to empirically investigate the interaction between profit sharing and innovative performance in Germany. Bellmann and Möller [2011] find that, throughout the period from 2001 to 2009, only about $9 \%$ of the total population of German firms employed this incentive system in addition to the normal wages. The percentage of companies sharing profits with employees heavily fluctuates according to size and industry affiliation, though. This percentage puts Germany on a mediocre rank, after France (57\%), the UK (40\%) and Sweden (20\%). Van Den Bulcke [1999] identifies factors yielding a less favourable environment with respect to financial participation (which is more general than mere profit sharing) of German employees: the German tax situation and social security, the complex legislation and the lack of a share ownership culture and tradition.

We constructed our database using various waves of the so-called IAB Establishment panel. Since 1993 (1996 for East Germany) the Institute for Employment Research (Institut für Arbeitsmarkt- und Berufsforschung: IAB) yearly surveys a panel of about 16,000 German companies. Based on size and industry affiliation, the sample of surveyed companies is randomly drawn from the employment statistics register of the German Federal Employment Agency (Bundesagentur für Arbeit). Because companies drop out due to non-response or market exit and new companies are continuously established, new companies are added to the sample every year, which results in an unbalanced panel structure. The survey gathers general company information on its establishment, turnover, staffing, investments, etc. but also leaves 
room for very specific questions, e.g. on public funding, innovation, technical equipment, etc. which are covered on an irregular basis, though.

Our key issue of interest is whether or not companies allow their employees to share in the profit. This information is reflected by the dummy variable PROF. Based on the theoretical arguments presented above, we advance the hypothesis that profit sharing exerts a positive impact on the innovative capabilities of a company. To test our hypotheses, we first select all manufacturing companies from the IAB Establishment Panel which use profit sharing in 2009 and compare them to a control group of companies which indicated that they did not employ profit sharing in their remuneration system in 2009 . We eliminate all the differences in exogenous variables to counter the selectivity issue, employing the matching method. Moreover we use a second sample consisting of firms which did not use profit sharing in 2005 but introduced it between 2005 and 2009. These firms are compared with those which did not apply profit sharing throughout the whole period in a conditional difference-in-differences framework. This will enable us to evaluate the impact of the introduction of a profit sharing system on a company's innovativeness.

The outcome to be evaluated is twofold: we test whether profit sharing fosters process and/or product innovation. We employ static matching and conditional difference-indifferences (CDiD). The matching procedure compares the values of our outcome variables in the year 2009. The CDiD computes the difference in growth rates for the variables of interest over the time period 2005 to 2009. In particular we proceed as follows. First, we evaluate the company's innovative strength with respect to technological capabilities. TECH measures the condition of a company's technical equipment on a five-point Likert scale, going from fully up-to-date (score $=1)$ to fully outdated ( information on the process innovation capabilities of a company, we believe that this variable is a good proxy. ADVNAR (ADV = advanced; NAR = narrow) and ADV indicate whether the company's technical equipment is fully up-to-date $(\mathrm{TECH}=1$ and $\mathrm{TECH}=2$ or 3 , respectively). In the CDID framework we use dynamic variables, reflecting the evolution of the condition of the technical equipment. The first dynamic variable is TECHch, measuring the difference in the condition of the technological equipment between 2009 and 2005. However, we deliberate about the trade off between the econometric inaccurateness of using the difference in an index value on the one hand and the full use of the available information on the other hand. That is why we additionally include a dummy variable reflecting the evolution of the company's technological equipment. We compute a variable indicating 
whether the company improved its technological strength and became a highly advanced technology user $($ ADVNARch $=1$ if TECH05 $\geq 2$ and TECH09 $=1)$. We expect all process innovation measures to be affected in a significantly positive way by the introduction of a profit sharing system.

Second, product innovation is evaluated.The information for 2005 was taken from the 2004 wave of the IAB panel, as product innovation was not covered in the 2005 wave. We assume that the innovative capability of 2004 is a good approximation for the innovativeness in 2005. INPDT indicates whether the company improved or further developed a product which was already comprised in the company's portfolio, within the last year (2008). ${ }^{4}$ NEWFRM measures whether the company adopted a product which was new to the firm, within the last year (2008). NEWMKT measures whether the company adopted a product which was new to the market, within the last year (2008). INNO equals 1 when at least one of the variables INPDT, NEWFRM or NEWMKT is 1 and hence labels companies as innovative or non-innovative in a very broad sense. For the CDID approach the dynamic variables are computed as the difference between 2009 and 2005: INPDTch (INPDT09-INPDT05), NEWFRMch (NEWFRM09-NEWFRM05), NEWMKTch (NEWMKT09-NEWMKT05) and INNOch (INNO09-INNO05). As argued in section 2, we expect to find indications that profit sharing affects a company's product innovation capabilities, in addition to the effect on the technical equipment. The impact on improvements or the introduction of new-to-the-firm products is expected to be stronger than the impact on the development of totally new (newto-the-market) products.

We use several control variables which may affect both the probability to employ a profit sharing remuneration system in addition to a fixed wage and innovative capability of a company, respectively. In the second sample where we analyse the effects of an introduction of profit sharing we use control variables in 2005 to estimate the probability to introduce profit sharing between 2005 and 2009. Including the number of employees (EMP) allows controlling for size effects, which are empirically often found to explain innovativeness (see e.g. Veugelers and Cassiman [1999]). Moreover, size may be related to the company's choice for a specific incentive scheme. For example, as smaller firms may be better aware of employees' individual performance, they may opt for other financial rewards than a profit sharing scheme. The logarithmic transformation (lnEMP) is used to smooth this variable. Next, we introduce a number of control variables related to the organizational structure of the firm: the ratio of qualified employees (QUAL) and dummies indicating a shift in 
responsibilities (SHIFT), the introduction of team work (TEAM) and independent work groups (INDEP) as well as positive investments in ICT infrastructure (ICT) reflect how a company responds to requirements of its environment. Complex and interdependent workflows imply more difficulties in measuring individual output. Moreover, information asymmetries and monitoring problems may be more pronounced. Also a range of variables characterizing how the company interacts with its direct stakeholders is important. First, a high level of trust between employees and managers facilitates consultation and fine-tunes cooperation engagements. The presence of a works council (COUNCIL) is a good proxy for this relationship. Second, the relationship between the company and the unions may be important. As we will explain in the following paragraph, Germany is a special case and the works council tends to substitute for the strength of the union, so the variable COUNCIL also reflects the union's power to some extent. In addition, we include a dummy variable (CAO) indicating whether a collective labour agreement is in place. Limited liability may foster the introduction of profit sharing; LTD has value 1 for joint stock companies (AG) and nonpublic limited liability companies $(\mathrm{GmbH})$. Moreover, profit sharing can be used to shift risks to the employees, which may be especially valuable for firms whose profits are risky. Thus, we include the export share (EXPORT) of firms. Last, some final company characteristics are added. After1990 is a dummy indicating whether the company was established after 1990, as profit sharing and age may interact. Also, firms located in East Germany (EAST $=1)$ may be less likely to introduce profit sharing (Möller [2002] as well as Bellman and Möller [2006]). Finally, industry affiliation may matter. We limit our sample to manufacturing firms, excluding agriculture, mining and construction and include 15 industry dummies (BR) in the analysis.

Our first sample for the matching approach consists of 1923 firms of which 385 use profit sharing in 2009. The second sample with introduction of profit sharing as treatment of interest includes observations of 1447 companies, of which 132 firms introduce profit sharing. In both cases, the first empirical step is the selection of a non-profit sharing twin company for each profit sharing firm. To this end, a propensity score is estimated in probit models, using the control variables introduced above. For both samples, the summary statistics of these variables (for the introduction sample in period $t_{0}=2005$ ) as well as the outcome variables for the introduction sample between the two periods $t_{0}=2005$ and $t_{1}=2009$ ) are presented in Table I. In both samples there are significant differences between firms with and without profit sharing in almost all of the considered determinants. 
A large body of literature addresses the correlation between a strong union presence on the one hand and R\&D and innovative activity on the other hand. This is highly relevant in the current paper, as the presence of a strong union may be correlated with our treatment as well as outcome variables. Menezes-Filho and Van Reenen [2003] survey the literature in this domain and conclude that North American studies consistently reveal a strongly negative correlation, while European studies cannot substantiate any significant impact of the union on R\&D and innovation. The studies investigating this issue in Germany are Addison and Wagner [1994], Schnabel and Wagner [1992a,b, 1994] as well as Fitzroy and Kraft [1990]. Schnabel and Wagner [1992b] ascribe the neutral relationship to the more cooperative nature of industrial relations in Germany.

The relevant labour institutions on the plant and firm level are the unions and also the works councils (see the Works Constitution Act ${ }^{5}$ ). Addison et al. [1996] point out that the German situation is highly specific, because the workplace representation occurs rather through the mechanism of the works council than through the union. As the ties between the union and the works council are very close, they suggest that the works council substitutes for the union institution in the German case. So, we feel confident here to assume that the presence of a works council and the union's bargaining power (variables COUNCIL and CAO) have no impact on the innovative activity in German firms. Adversely, these variables are expected to have an impact on the propensity to introduce profit sharing, i.e. our treatment variable.

After the matching, the evolution in the outcome variables (both static and dynamic) is evaluated for the subsample of matched pairs. This approach eliminates a considerable share of observed as well as unobserved heterogeneity in the treated and non-treated firms in the population and mitigates the potential selectivity bias. The CDiD approach conducts twosided t-tests to compare the means of the two groups after the matching.

\section{Estimates}

The potential presence of selectivity in this evaluation exercise was introduced in the methodological section. Because of this potential endogeneity, a simple comparison of the outcome variables between companies with and without profit sharing (as presented in Table I) does not provide an adequate answer in this evaluation research; the introduction of profit 
sharing may be induced by innovativeness. We observe significant differences in the innovative strength between profit sharing companies and the potential control group. However, the control variables differ significantly as well and these differences may also explain differences in innovativeness. We address this potential selection bias empirically starting from nearest neighbour propensity score matching. Then we switch to the CDiD approach to assess the evolution of the outcome variables over time. This technique ensures that both observable and unobservable differences between treated and non-treated companies are taken into account, as well as any macro-economic change over time. We believe that the data at hand is sufficiently rich and that the matching procedure significantly curtails the selection bias. As a result, any potentially remaining difference in the outcome variables can be attributed to the introduction of profit sharing ${ }^{6}$.

To select a non-profit sharing twin company for each profit sharing company, we first estimate the propensity scores, which reflects the probability that a company remunerates its employees with a system of profit sharing in addition to a fixed wage. The two models for existence and introduction of profit sharing are presented in Table II. In both probit models, size (lnEMP), the presence of a works council (COUNCIL), investment in ICT (ICT) and the export share (EXPORT) are significant. For existence of profit sharing in the first sample, also the share of qualified employees (QUAL) positively affects the probability to use profit sharing. These estimates confirm expectations formulated in the section on selectivity. Smaller companies rather opt for other incentive schemes than profit sharing. The presence of a works council, reflecting a high level of trust between company owners and employees, also create a favourable setting for a profit sharing incentive scheme.

--- Place Table II approximately here ---

The probit model provides estimated propensity scores and enables us to select similar companies. After the matching process, any difference in the control variables is eliminated and the remaining differences in outcome variables can be attributed to the existence/introduction of a profit sharing system. In the first analysis, we evaluate differences for the outcome variables in 2009 between the profit sharing firms and their selected twin partners, respectively. The upper part of Table III shows the difference in outcome variables, which reflect innovative capabilities. Profit sharing companies are more likely to have a fully up-to-date technical equipment (TECH). They are only somewhat more eager to use advanced technologies (ADV is marginally significant and ADVNAR is insignificant) The lower part of Table III shows that additionally controlling for unobservable differences leads to different 
results. We do not find evidence that companies introducing profit sharing experience a stronger development in the process innovation variables (TECHch, ADVNARch) compared to firms without profit sharing.

In the static approach, also the outcome variables measuring product innovation significantly differ after the matching. We notice that profit sharing companies are more likely to have improved a product in the company's existing portfolio (INPDT), introduced a new-to-the-firm product (NEWFRM marginally significant) and even a new-to-the-market product (NEWMKT). The general measure on product innovativeness shows that they are more innovative in comparison with companies that did not introduce profit sharing (INNO). As profit sharing increases employee involvement in the innovation process, they are more likely to disclose relevant and valuable information. Our expectation was that the impact of profit sharing is larger with respect to process than product innovation. However, most of the dynamic variables reflecting the change in companies' product innovation capabilities point to the existence of effects, which is however not the case for product innovation. The introduction of profit sharing is associated with a significant (on the 5\% level) increase of products which are new to the firm (NEWFRMch), and we find weakly significant impacts with respect to improvements and further development of already existing products (INPDTch) and the encompassing variable standing for product innovation in general INNOch (lower part of Table III). In contrast, based on the conditional difference-indifferences framework we cannot find evidence in favour of the introduction of products new for the market. These results are in accordance with our expectations that employees' involvement is more beneficial for improvements of existing products and introduction of products new to the firm than it is for innovations new to the market.

It is perhaps surprising that the conditional difference-in-differences models show a strong impact of profit sharing on product innovation but none for process innovation. However, as it is well known the lack of statistical evidence is not the proof of absence of a relation. One reason for no statistical evidence may be weak measurement. The variables available for determining technical progress are based on scales, which imply subjective evaluations of the state of technical progress by the management. This subjective evaluation may well change without a true reason within the same establishment from one year to the other, in particular if the responding person is not the same The variables concerning product innovation offer less room for individual and subjective evaluations. 
Furthermore in case of difference-in-differences our conclusions are based on just 132 establishments, which introduce profit sharing during the relevant period. Hence while taking account of unobserved heterogeneity is surely useful, more observations with changes in the relevant variable would be most helpful in identifying possible effects.

--- Place Table III approximately here ---

\section{Conclusion}

We empirically investigated the impact of profit sharing on the innovative capabilities of German manufacturing companies. Since the introduction of a profit sharing system may be endogenous, we employ matching and the CDiD approach. Once the potential selection bias is eliminated, in a static approach companies with and without a profit sharing system still differ significantly in their innovativeness. Profit sharing companies outperform nonprofit sharing companies on both process and product innovativeness. However, according to the results of the CDiD method only product innovation is enhanced by the introduction of profit sharing. Hence firms introducing profit sharing are already more innovative before they launch the variable incentive method of profit sharing, with respect to both product and process innovations. However, profit sharing additionally has a positive effect on product innovations.

In Bellmann and Möller [2006] two profiles of companies introducing profit sharing emerge. On the one hand profit sharing companies are the larger companies with a complex working environment, introducing profit sharing to motivate the workforce. On the other hand also small and young, technology-oriented firms introduce profit sharing as they do not have substantial resources to attract and keep highly qualified employees; the profit premium is treated as a bonus to the regular pay slip. The firms in our sample, introducing profit sharing, are mainly the larger firms, with a more complex work environment and a high level of trust between employees and managers. The ownership structure as well as industry affiliation is relevant, too. The age of the company does not seem to matter. Therefore, the firms in our sample seem to belong mainly to the first profile. Hence, the impact of profit sharing on innovativeness may be different in smaller high-tech firms.

The results presented in this paper establish valid proof supporting the hypotheses developed on the impact of profit sharing on a company's innovative activity. However, as new survey waves will become available and existing datasets may be extended, robustness 
checks, e.g. with different specifications of the moment when the economic return becomes apparent, different measures of innovativeness, etc. will provide valuable additional insights into this domain. We already discussed the limitations of our variables on process innovations and perhaps over time also alternative measures on process innovations will become available.

An interesting point of view was advanced by Lerner and Wulf [2007], who link different incentive schemes to reward $R \& D$ managers to patenting activity. Also the size of the profit premium, instead of mere stochastic information on the application of this remuneration scheme, could yield an interesting path for further research, as the impact of profit sharing may be heterogeneous in size.

Although our results suggest that profit sharing adds to companies' innovative capacity, the share of German companies actually employing this system is rather limited in comparison with other countries (especially France and the UK). Research on the obstacles hampering German employers to let employees share in the profit indicates an unfavourable taxation system, the complex legislation system as well as a bad fit with the cultural background as key problems (Van Den Bulcke [1999]). Therefore, German policy makers may consider designing a more profit sharing friendly environment for German companies. Besides the potential positive productivity and employment gains, also the national innovative capacity may benefit from this remuneration system.

\section{References}

Addison, J.T., Schnabel, C. and Wagner, J., 1996, 'German works councils, profits, and innovation', Kyklos, 49(4), pp. 555-582.

Addison, J.T. and Wagner, J. 1994, 'UK Unionism and Innovative Activity: Some Cautionary Remarks on the Basis of a Simple Cross-Country Test', British Journal of Industrial Relations, 32(1), pp. 85-98.

Aerts, K. and Schmidt, T., 2008, 'Two for the price of one? On additionality effects of R\&D subsidies: A comparison between Flanders and Germany', Research Policy, 37(5), pp. $806-822$.

Bellmann, L. and Möller, I., 2006, 'Die Betriebe in Deutschland haben Nachholbedarf', Institut für Arbeitsmarkt- und Berufsforschung (IAB) Kurzbericht n ${ }^{\circ} 13$ / 5.9.2006. 
Bellmann, L. and I. Möller, 2011, Finanzielle Mitarbeiterbeteiligung - Selbst die Finanzkrise sorgt nicht für stärkere Verbreitung, IAB-Kurzbericht nº 17/2011.

Bergemann, A., Fitzenberger, B. and Speckesser, S., 2004, 'Evaluating the Dynamic Employment Effects of Training Programs in East Germany Using Conditional Differencein-Differences', ZEW Discussion Paper $n^{\circ}$ 04-41, Centre for European Economic Research (ZEW), Mannheim.

Bhargava, S. and Jenkinson, T., 1995, 'Explicit versus Implicit Profit Sharing and the Determination of Wages', Labour, 9(1), pp. 73-95.

Blundell, R. and Costa Dias, M., 2000, 'Evaluation Methods for Non-Experimental Data', Fiscal Studies, 21(4), pp. 427-468.

Blundell, R. and Costa Dias, M. (2009), 'Alternative Approaches to Evaluation in Empirical Microeconomics', Journal of Human Resources, vol. 44 (3), 565-640.

Commission of the European Communities, 1991. PEPPER I Report: Promotion of employee participation in profits and enterprise results, supplement 3/91, Brussels.

Commission of the European Communities, 1996. PEPPER II Report: Promotion of employee participation in profits and enterprise results, $\operatorname{COM}(96) 697$, Brussels.

Coombs, G. and Gomez-Mejia, L.R., 1991, 'Cross-functional compensation strategies in high technology firms', Compensation and Benefits Review, 23(5), pp. 40-48.

Dasgupta, P. and Maskin, E., 1987, 'The Simple Economics of Research Portfolios', The Economic Journal, 97(3), pp. 581-595.

Doucouliagos, C., 1995, 'Worker Participation and Productivity in Labour-Managed and Participatory Capitalist Firms: A Meta-Analysis', Industrial and Labour Relations Review, 49(1), pp. 58-77.

Eichler, M. and Lechner, M., 2002, 'An Evaluation of Public Employment Programmes in the East German State of Sachsen-Anhalt', Labour Economics, 9(2), pp. 143-186.

FitzRoy, F. and Kraft, K., 1987, 'Cooperation, Productivity and Profit Sharing', Quarterly Journal of Economics, 102(1), pp. 23-35.

Fitzroy, F. and Kraft, K., 1990, 'Innovation, Rent-Sharing and the Organization of Labour in the Federal Republic of Germany', Small Business Economics, 2(4), pp. 95-103.

FitzRoy, F. and Kraft, K., 1995, 'On the Choice of Incentives in the Firm', Journal of Economic Behaviour and Organization, 26(1), pp. 145-160.

Halaby, C.N., 2004, 'Panel models in sociological research: Theory into practice', Annual Review of Sociology, 30, pp. 507-544. 
Heckman, J.J., Ichimura, H. and Todd, P., 1997, 'Matching as an Econometric Evaluation Estimator: Evidence from evaluating a job training programme', Review of Economic Studies, 64(4), pp. 605-654.

Kluve, J., Lehmann, H. and Schmidt, C.M., 1999, Active Labour Market Policies in Poland: Human Capital Enhancement, Stigmatization or Benefit Churning?, Journal of Comparative Economics, 27(1), pp. 61-89.

Kraft, K. and Ugarkovic, M. (2006), 'Profit Sharing and the Financial Performance of Firms: Evidence from Germany’ (2006), Economics Letters, vol. 92, 333-338.

Kraft, K. and Ugarković, M., 2007, Profit-Sharing: Supplement or Substitute?, mimeo University of Dortmund, Dortmund.

Lechner, M., 1998, Training the East German labour force: microeconometric evaluations of continuous vocational training after unification, Heidelberg.

Lerner, J. and Wulf, J., 2007, 'Innovation and incentives: evidence from corporate R\&D', The Review of Economics and Statistics, 89(4), pp. 634-644.

Lowitzsch, J., 2006, Commission of the European Communities, 1996, PEPPER III Report: Promotion of employee participation in profits and enterprise results in the New Member and Candidate Countries of the European Union.

Mansfield, E., 1985, 'How rapidly does new industrial technology leak out?', The Journal of Industrial Economics, 34(2), pp. 217-223.

Menezes-Filho, N. and Van Reenen, J., 2003, Unions and innovation: a survey of the theory and empirical evidence, CEPR Discussion Paper $n^{\circ} 3792$, London.

Möller, I., 2002, Produktivitätswirkung von Mitarbeiterbeteiligung: Der Einfluss von unbeobachteter Heterogenität, MittAB, 1, pp. 123-132.

Pendleton, A., Poutsma, E., van Ommeren, J. and Brewster, Ch., 2005, Employee share ownership and profit-sharing in the European Union, The European Foundation for the Improvement of Living and Working Conditions, Dublin.

Pérotin, V. and Robinson, A., 2002, Employee participation in profit and ownership: A review of the issues and evidence, Leeds University Business School, Leeds.

Poutsma, E., 2001, Recent Trends in Employee Financial Participation in the European Union, Office for the Official Publications of the European Communities, Luxembourg.

Romer, P.M., 1990, 'Endogenous Technological Change', Journal of Political Economy, 98(5), pp. 71-102.

Rosenbaum, P.R. and Rubin, D.B., 1983, 'The Central Role of the Propensity Score in Observational Studies for Causal Effects', Biometrika, 70, pp. 41-55. 
Roy, A.D., 1951, 'Some Thoughts on the Distribution of Earnings', Oxford Economic Papers, 3(2), pp. 135-146.

Rubin, D.B., 1974, 'Estimating Causal Effects of Treatments in Randomized and NonRandomized Studies', Journal of Educational Psychology, 66, pp. 688-701.

Rubin, D.B., 1977, 'Assignment to Treatment Group on the Basis of Covariate', Journal of Educational Statistics, 2, pp. 1-26.

Schaefer, S., 1998, 'Influence costs, structural inertia, and organizational change', Journal of Economics \& Management Strategy, 7(2), pp. 237-263.

Schnabel, C. and Wagner, J., 1992a, 'Unions and Innovative Activity in Germany', Journal of Labour Research, 13(8), pp. 393-406.

Schnabel, C. and Wagner, J., 1992b, 'Unions and Innovations: Evidence from Germany', Economics Letters, 39, pp. 369--73.

Schnabel, C. and Wagner, J., 1994, 'Industrial Relations and Trade Union effects on Innovation in Germany', Labour, 8(3), pp. 489-503.

Schumpeter, J.A., 1942, Capitalism, socialism and democracy (Harper \& Brothers, New York).

Strotmann, H., 2002, Zur Bedeutung materieller Mitarbeiterbeteiligung in BadenWürttemberg - eine empirische Analyse mit dem IAB-Betriebspanel, IAW report, Institut für angewandte Wirtschaftsforschung (IAW), Tübingen.

Van Den Bulcke, F., 1999, A company perspective on financial participation in the European Union: Objectives and obstacles, Report, Research Centre for Financial Participation, K.U. Brussel, Brussels.

Veugelers, R. and Cassiman, B., 1999, 'Make or buy in innovation strategies: evidence from Belgian manufacturing firms', Research Policy, 28(1), pp. 63-80.

Wadhwani, S. and Wall, M., 1990, 'The effects of profit-sharing on employment, wages, stock returns and productivity: evidence from UK micro-data', Economic Journal, 100(399), pp. 1-17.

Weitzman, M.L., 1983, Some Macroeconomic Implications of Alternative Compensation Systems, The Economic Journal, 93(372), pp. 763-783.

Wooldridge, J.M., 2002, Econometric analysis of cross section and panel data (Massachusetts Institute of Technology Press, Cambridge/London).

Zwick, T., 2002, 'Empirical determinants of employee resistance against innovations', International Journal of Manpower, 23(6), pp. 542-552. 
Table I: Summary statistics before the matching

\begin{tabular}{|c|c|c|c|c|}
\hline Variable & period & ring firms & $\begin{array}{c}\text { Potential control group } \\
\text { Mean }\end{array}$ & Difference \\
\hline \multicolumn{5}{|c|}{ Sample "Existence of profit sharing" 2009} \\
\hline \multicolumn{5}{|c|}{ OUTCOME VARIABLES } \\
\hline \multicolumn{5}{|c|}{ Process innovation } \\
\hline TECH & 2009 & 2.134 & 2.314 & $0.179 * * *$ \\
\hline ADVNAR & 2009 & 0.164 & 0.136 & $0.029 *$ \\
\hline ADV & 2009 & 0.717 & 0.605 & $0.063 * *$ \\
\hline \multicolumn{5}{|c|}{ Product innovation } \\
\hline INPDT & 2009 & 0.801 & 0.486 & $0.315 * * *$ \\
\hline NEWFRM & 2009 & 0.419 & 0.254 & $0.165 * * *$ \\
\hline NEWMKT & 2009 & 0.230 & 0.105 & $0.125 * * *$ \\
\hline INNO & 2009 & 0.833 & 0.757 & $0.076 * * *$ \\
\hline \multicolumn{5}{|c|}{ CONTROL VARIABLES } \\
\hline $\operatorname{lnEMP}$ & 2009 & 4.958 & 3.252 & $1.706 * * *$ \\
\hline QUAL & 2009 & 0.140 & 0.056 & $0.085 * * *$ \\
\hline SHIFT & 2009 & 0.186 & 0.119 & $0.067 * * *$ \\
\hline TEAM & 2009 & 0.145 & 0.065 & $0.081 * * *$ \\
\hline INDEP & 2009 & 0.109 & 0.049 & $0.059 * * *$ \\
\hline ICT & 2009 & 0.667 & 0.349 & $0.318 * * *$ \\
\hline COUNCIL & 2009 & 0.682 & 0.274 & $0.409 * * *$ \\
\hline $\mathrm{CAO}$ & 2009 & 0.589 & 0.397 & $0.192 * * *$ \\
\hline LTD & 2009 & 0.938 & 0.651 & $0.287 * * *$ \\
\hline EAST & 2009 & 0.385 & 0.551 & $-0.166^{* * *}$ \\
\hline EXPORT & 2009 & 0.791 & 0.424 & $0.367 * * *$ \\
\hline Number of obs.: & & 385 & 1538 & \\
\hline \multicolumn{5}{|c|}{ Sample "Introduction of profit sharing" $2005-2009$} \\
\hline \multicolumn{5}{|c|}{ OUTCOME VARIABLES } \\
\hline \multicolumn{5}{|c|}{ Process innovation } \\
\hline TECHch & 2005-2009 & 0.052 & 0.026 & 0.029 \\
\hline ADVNARch & 2005-2009 & 0.075 & 0.064 & 0.011 \\
\hline \multicolumn{5}{|c|}{ Product innovation } \\
\hline INPDTch & 2005-2009 & 0.134 & 0.014 & $0.120 * *$ \\
\hline NEWFRMch & 2005-2009 & 0.149 & 0.023 & $0.126 * * *$ \\
\hline NEWMKTch & 2005-2009 & 0.067 & 0.019 & 0.048 \\
\hline INNOch & $2005-2009$ & 0.112 & 0.025 & $0.087 *$ \\
\hline \multicolumn{5}{|c|}{ CONTROL VARIABLES } \\
\hline $\operatorname{lnEMP}$ & 2005 & 4.446 & 3.061 & $1.385 * * *$ \\
\hline QUAL & 2005 & 0.300 & 0.220 & $0.080 * * *$ \\
\hline SHIFT & 2005 & 0.142 & 0.109 & 0.033 \\
\hline TEAM & 2005 & 0.097 & 0.058 & $0.061 *$ \\
\hline INDEP & 2005 & 0.119 & 0.041 & $0.079 * * *$ \\
\hline ICT & 2005 & 0.716 & 0.418 & $0.299 * * *$ \\
\hline COUNCIL & 2005 & 0.567 & 0.228 & $0.339 * * *$ \\
\hline $\mathrm{CAO}$ & 2005 & 0.552 & 0.396 & $0.156 * * *$ \\
\hline LTD & 2005 & 0.881 & 0.603 & $0.278 * * *$ \\
\hline EAST & 2005 & 0.433 & 0.559 & $-0.126^{* * *}$ \\
\hline EXPORT & 2005 & 0.709 & 0.369 & $0.340 * * *$ \\
\hline Number of obs.: & & 132 & 1315 & \\
\hline
\end{tabular}


Table II: Propensity to employ profit-sharing

\begin{tabular}{|c|c|c|c|}
\hline \multicolumn{4}{|c|}{ "Sample "Existence of profit sharing" 2009} \\
\hline & \multicolumn{3}{|c|}{ Probit estimates } \\
\hline & \multicolumn{2}{|c|}{ Coef. } & \multirow{2}{*}{ Std. Err. } \\
\hline $\operatorname{lnEMP}$ & 0.154 & $* * *$ & \\
\hline QUAL & 1.574 & $* * *$ & 0.312 \\
\hline $\mathrm{SHIFT}^{\circ}$ & -0.12 & & 0.105 \\
\hline TEAM $^{\circ}$ & 0.231 & $*$ & 0.121 \\
\hline $\mathrm{INDEP}^{\circ}$ & 0.072 & & 0.140 \\
\hline $\mathrm{ICT}^{\circ}$ & 0.274 & $* * *$ & 0.081 \\
\hline $\mathrm{COUNCIL}^{\circ}$ & 0.265 & $* *$ & 0.109 \\
\hline $\mathrm{CAO}^{\circ}$ & -0.026 & & 0.091 \\
\hline $\mathrm{LTD}^{\circ}$ & 0.229 & $*$ & 0.128 \\
\hline AFTER $1990^{\circ}$ & 0.057 & & 0.095 \\
\hline EAST $^{\circ}$ & -0.159 & & 0.097 \\
\hline EXPORT & 0.230 & $* *$ & 0.094 \\
\hline constant & -1.924 & $* * *$ & 0.271 \\
\hline Log-Likelihood & \multicolumn{3}{|c|}{-745} \\
\hline Pseudo $\mathrm{R}^{2}$ & \multicolumn{3}{|c|}{0.226} \\
\hline \# obs. & \multicolumn{3}{|c|}{1923} \\
\hline
\end{tabular}

Sample "Introduction of profit sharing" 2005-2009

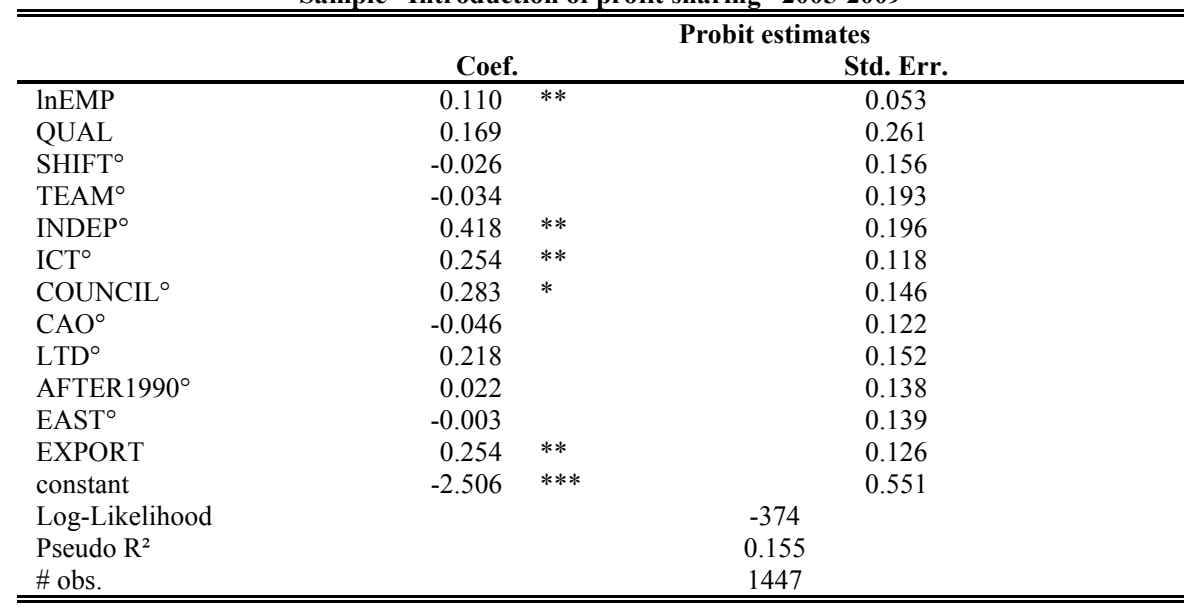

*** $(* *, *)$ indicate a significance level of $1 \%(5,10 \%)$. Industry dummies (BR) included. 
Table III: Outcome variables matched samples

\begin{tabular}{|c|c|c|c|c|}
\hline & $\begin{array}{c}\text { Profit-sharing firms } \\
\text { Mean }\end{array}$ & $\begin{array}{c}\text { Selected control group } \\
\text { Mean }\end{array}$ & & \\
\hline \multicolumn{5}{|c|}{ Sample "Existence of profit sharing" 2009} \\
\hline \multicolumn{5}{|c|}{ Process innovation } \\
\hline $\mathrm{TECH}$ & 2.136 & 2.251 & -0.115 & $* *$ \\
\hline ADVNAR & 0.165 & 0.136 & 0.029 & \\
\hline ADV & 0.716 & 0.653 & 0.063 & $*$ \\
\hline \multicolumn{5}{|c|}{ Product innovation } \\
\hline INPDT & 0.802 & 0.715 & 0.086 & $* * *$ \\
\hline NEWFRM & 0.420 & 0.360 & 0.060 & $*$ \\
\hline NEWMKT & 0.230 & 0.149 & 0.081 & $* * *$ \\
\hline INNO & 0.833 & 0.757 & 0.076 & $* * *$ \\
\hline \multicolumn{5}{|c|}{ Sample "Introduction of profit sharing" $2005-2009$} \\
\hline \multicolumn{5}{|c|}{ Process innovation } \\
\hline TECHch & 0.047 & 0.102 & -0.055 & \\
\hline ADVNARch & 0.078 & 0.055 & 0.023 & \\
\hline \multicolumn{5}{|c|}{ Product innovation } \\
\hline INPDTch & 0.133 & 0.000 & 0.133 & $*$ \\
\hline NEWFRMch & 0.141 & -0.039 & 0.180 & $* *$ \\
\hline NEWMKTch & 0.070 & 0.008 & 0.063 & \\
\hline INNOch & 0.117 & -0.008 & 0.125 & $*$ \\
\hline \multicolumn{5}{|c|}{$\begin{array}{l}\text { Note: the control variables (InEMP, QUAL, SHIFT, TEAM, INDEP, ICT, COUNCIL, CAO, LTD, AFTER1990, } \\
\text { EAST, EXPORT and BR) as well as the propensity score are not significantly different after the matching and } \\
\text { therefore not reported here. } * * *(* * *) \text { indicate a significance level of } 1 \%(5,10 \%) \text { of the t-tests on mean equality } \\
\text { between the sample of funded firms and the selected control group. } \theta \text { is the average treatment effect of profit- } \\
\text { sharing. }\end{array}$} \\
\hline
\end{tabular}




\section{Footnotes}

\footnotetext{
${ }^{1}$ Also 'capital sharing' exists, a system in which employees hold shares of the company and in this sense, become co-owners of the company. This issue lies beyond the framework of this paper, though.

${ }^{2}$ For the sake of readability we omit firm indices in the equations.

${ }^{3}$ CdiD can also be applied for repeated cross section. Cf. for a description of this method Blundell and Costa Dias (2009) and for an application Aerts and Schmidt (2008).

${ }^{4}$ In 2004 all questions on process innovations are asked with respect to innovations within the two preceding years.

${ }^{5}$ This Works Constitution Act (Betriebsverfassungsgesetz) was issued in 1972.

${ }^{6}$ Difference-in-differences controls for common time trends and permanent differences between the two groups considered. Therefore a crucial assumption of diff-in-diff is that firms with and without profit sharing do not seriously change in their characteristics over time. (Time-invariance of unobserved individual factors.) These assumptions must be valid in order that this approach works (see e.g. Blundell and Costa Dias, 2009). Our time period considered (2005-2009) seems to be rather long, but it is quite unlikely that any effect on innovation will occur and will be measured during a shorter time period.
} 